\title{
Population dynamics of the date mussel, Lithophaga lithophaga (L., 1758) (Bivalvia : Mytilidae), in the Evoikos Gulf (Greece)
}

\author{
S. Galinou-Mitsoudi \& A. I. Sinis* \\ Aristotle University of Thessaloniki, Department of Zoology; P. O. Box 134, \\ 54006 Thessaloniki, Greece
}

\begin{abstract}
Changes with time in a Lithophaga lithophaga population, spatial distribution, size-frequency distribution and recruitment were studied. The population was homogenous, without statistically significant differences, down to a depth of $6 \mathrm{~m}$, the depth to which sampling was carried out. Population density showed periodic variations over the year and changed as the gradient of the substratum increased. Dispersion indices indicated that individuals were distributed randomly in clumps during the period of recruitment at different depths. Juveniles, up to a length of $4 \mathrm{~mm}$, formed the highest percentage of the population. Larvae settled at a length of $>260 \mu \mathrm{m}$, and individuals reached a length of $35 \mathrm{~mm}$ by the end of their first year. The appearance of newly settled individuals occurred two months after the maximum occurrence of larvae in the water. High percentages of settled spat were first observed in early winter at a depth of between 0-3 m although, later, higher percentages were found at 3-6 $\mathrm{m}$ depth.
\end{abstract}

\section{INTRODUCTION}

Lithophaga lithophaga lives in hard substrata, and this presents a problem for quantitative sampling. To date, only one quantitative study exists for this well-known Mediterranean species and is related to population density (Kleemann, 1973). Kleemann found few individuals $\leq 10 \mathrm{~mm}$ and, at most, these represented about $10 \%$ of the total number of individuals in the sample. In this study, a quantitative approach to the changes with time in a population of $L$. lithophaga has been taken. The study was carried out in the North Evoikos Gulf (Fig. 1) over a period of 20 months from April 1989 until November 1990 when monthly samples were collected.

Recruited individuals (post larvae, spat or juveniles) have a metamorphosis line which separates the prodissoconch II from the dissoconch (Lutz \& Hidu, 1979). According to Kautsky (1982), recruitment is divided into two phases: (a) those individuals which settle and (b) those which will renew the stock. These phases are related to the viability of small individuals which are divided according to size (length) into: (a) postlarvae (Webb, 1986) where the density is expressed as numbers per surface area (Connell, 1985, cited in Menge, 1991); (b) juveniles or newly hatched individuals with lengths $>1 \mathrm{~mm}$

\footnotetext{
- Address for correspondence: Dr. A. Sinis, University of Thessaloniki, Department of Zoology, P.O. Box 134, 54006 Thessaloniki, Greece
} 
(Le Pennec, 1980; Lutz et al., 1982; Webb, 1987) and (c) spat, which in calculations are referred to as recruited individuals and are classified as age 0+ (Muus, 1973). The juveniles and spat $(b, c)$ survive settlement and represent recruitment density (Connell, 1985 cited in Menge, 1991). Thereafter, the term recruitment refers to individuals which are $>400 \mu \mathrm{m}$ and $<4 \mathrm{~mm}$ in length (Muus, 1973).

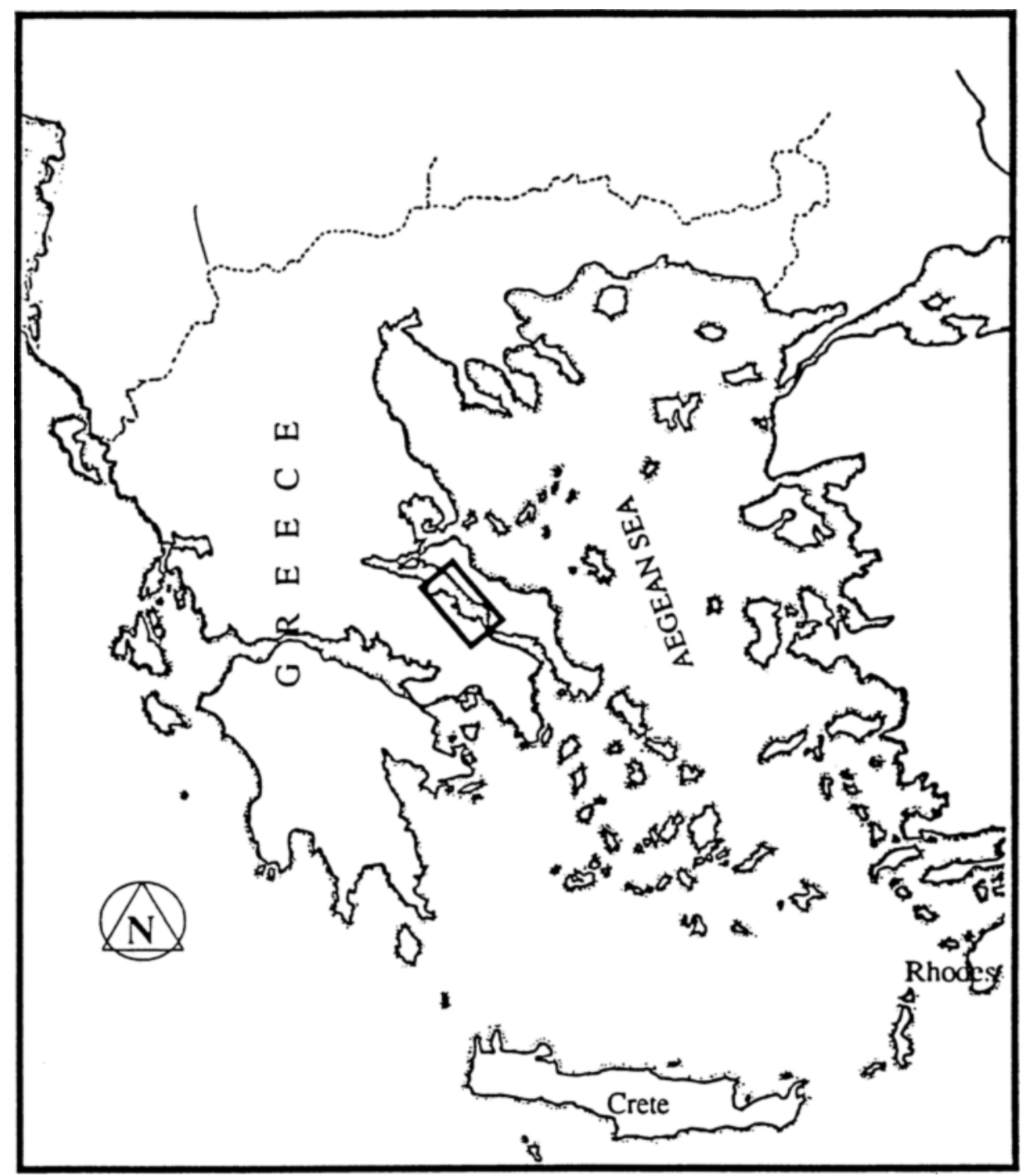

Fig. 1. Map of the study area, showing N. Evoikos Gulf (inset) 


\section{MATERIALS AND METHODS}

\section{Sampling}

Random pieces of rock suitable for colonisation by Lithophaga lithophaga were collected monthly (April 1989 - November 1990) by SCUBA diving from a region of the N. Evoikos Gulf (Fig. 1), at depths of up to $6 \mathrm{~m}$. One sample of isolated rocks from a depth of between 6-8 m was also obtained.

During sampling, water temperatures, dissolved oxygen and salinity were measured at sea surface and sea bottom.

In order to study recruitment, monthly plankton samples were collected vertically, and the depth and number of samples (not less than 4) were recorded. A plankton net (diameter $25 \mathrm{~cm}$ ) with a mesh size of $50 \mu \mathrm{m}$ was used from October 1989 to November 1990. The total number of bivalve larvae and the number of $L$. lithophaga larvae per $\mathrm{m}^{3}$ of water were counted in the monthly samples.

The numbers of postlarvae which settled on new substratum (pieces of rock placed at depths of $1 \mathrm{~m}$ in March 1990) were counted to determine the duration of the larval stage and the time of settlement. The density of spat was expressed as the numbers of individuals with a length $\leq 4 \mathrm{~mm} / \mathrm{dm}^{3}$ substratum, and variations with time and depth were determined.

\section{Population density and homogeneity}

The living individuals of $L$. hithophaga were described as numbers per unit net volume of the removed substratum $\left(1 \mathrm{dm}^{3}\right)$, after the removal of other organisms (algae and animals).

The surface removed from the rocky bottom of 24 sampling units was measured and the derived surface area of the samples compared with a quadrat of $20 \times 20 \mathrm{~cm}\left(0.04 \mathrm{~m}^{2}\right)$ because some studies refer to quadrats either of $20 \times 20$ or $25 \times 25 \mathrm{~cm}$. The values of the population density (individuals $/ \mathrm{dm}^{3}$ ) were logarithmically transformed; the Levene-test, to test for the homogeneity of the variations, and two-way ANOVA with respect to time and depth (Zar, 1984) were applied.

The volume of L. lithophaga and the net substrate volume were also measured.

\section{Index of precision}

The precision index (D) was determined on the basis of the average number of individuals $(\overline{\mathrm{x}})$ in each sampling unit and the variance $\left(\mathrm{s}^{2}\right)$ of $\overline{\mathrm{x}}$ (Elliott, 1983):

$$
D=\frac{1}{\bar{x}} \sqrt{\frac{s^{2}}{n}}
$$

where $\mathrm{n}$ is the number of sampling units in each sample. Six sampling units $(n=6)$ were chosen per sample, except for the first sample $(n=5)$, so that precision index was less than $20 \%$. 


\section{Spatial distribution}

Initially, the dispersion index $I=\frac{s^{2}}{\bar{x}}$ (Elliott, 1983) was used, where $s^{2}$ is the variance of the population and $\bar{x}$ the average number of individuals in each sampling unit. This index depends strongly on the number of individuals $(x)$ in each sampling unit, given that $n, x$ and $\Sigma x$ are the same for each sample. If the values of the index are:

$=1$, the distribution of individuals is random

$<1$, the distribution of individuals is normal and

$>1$, the distribution of individuals is contagious

In cases of deviation from 1 an $\chi^{2}-$ test was used:

$$
\chi^{2}=\frac{s^{2}(n-1)}{\bar{x}}
$$

For more detailed analysis the Morisita index (Iס) (Elliott, 1983) was used:

$$
I \delta=n \frac{\Sigma\left(x^{2}\right)-\Sigma x}{(\Sigma x)^{2}-\Sigma x}
$$

where $\mathrm{x}$ is the number of individuals in a sampling unit and $\mathrm{n}$ is the number of sampling units in each sample. This index is independent of the $\bar{x}$ of the sampling units and the total number of individuals in the samples $(\Sigma x)$, but is dependent on the number of $n$ in each sample. When this index is:

$=1$, the spatial distribution is random

$<1$, the spatial distribution is normal

$>1$, the spatial distribution is contagious

In cases of deviation from 1, an $\chi^{2}$ - test was used: $\chi^{2}=I \delta(\Sigma x-1)$ tn $-\Sigma x$ (Elliott, 1983).

An index similar to I $\delta$ was also used, i.e. the index of mean crowding (Lloyd, 1967. cited in Elliott, 1983):

$$
\dot{\mathrm{m}}=\overline{\mathrm{x}}+\left(\frac{\mathrm{s}^{2}}{\overline{\mathrm{x}}}-1\right)
$$

which is of the form $y=a+b x$.

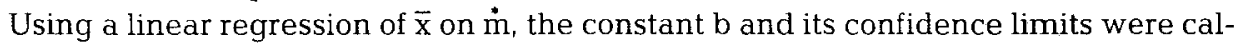
culated. When $b=1$ the distribution is random as is the equation of Taylor (Elliott, 1983) with the difference that the index of mean crowding $(\dot{m})$ is not affected by the density of the individuals in the sample, but by the number of sampling units.

\section{RESULTS}

\section{Population}

The population of Lithophaga lithophaga in the study area was homogeneous in respect of the variance of samples (Levene-test, ANOVA : $F=1.26, P=0.288$ ). No statistically significant differences were noticed (two-way ANOVA) with depth $(\mathrm{F}=1.556, \mathrm{P}=$ 0.293). Variations in population density were, however, recorded between different months $(\mathrm{F}=2.385, \mathrm{P}=0.013)$.

There were seasonal changes in the population density of L. lithophaga in the study 
area during 1989-1990 (Fig. 2). The average population density during the course of the study was $35.83 \pm 6.67$ individuals $/ \mathrm{dm}^{3}$ and covered $23.15 \pm 0.045 \%$ SD of the net substratum volume. There was no difference between the average values of population density for 1989 and 1990 , i.e. $32.67 \pm 8.55$ and $38.42 \pm 3.11$ individuals $/ \mathrm{dm}^{3} \mathrm{SD}$, respectively $(\mathrm{P}=0.05)$.

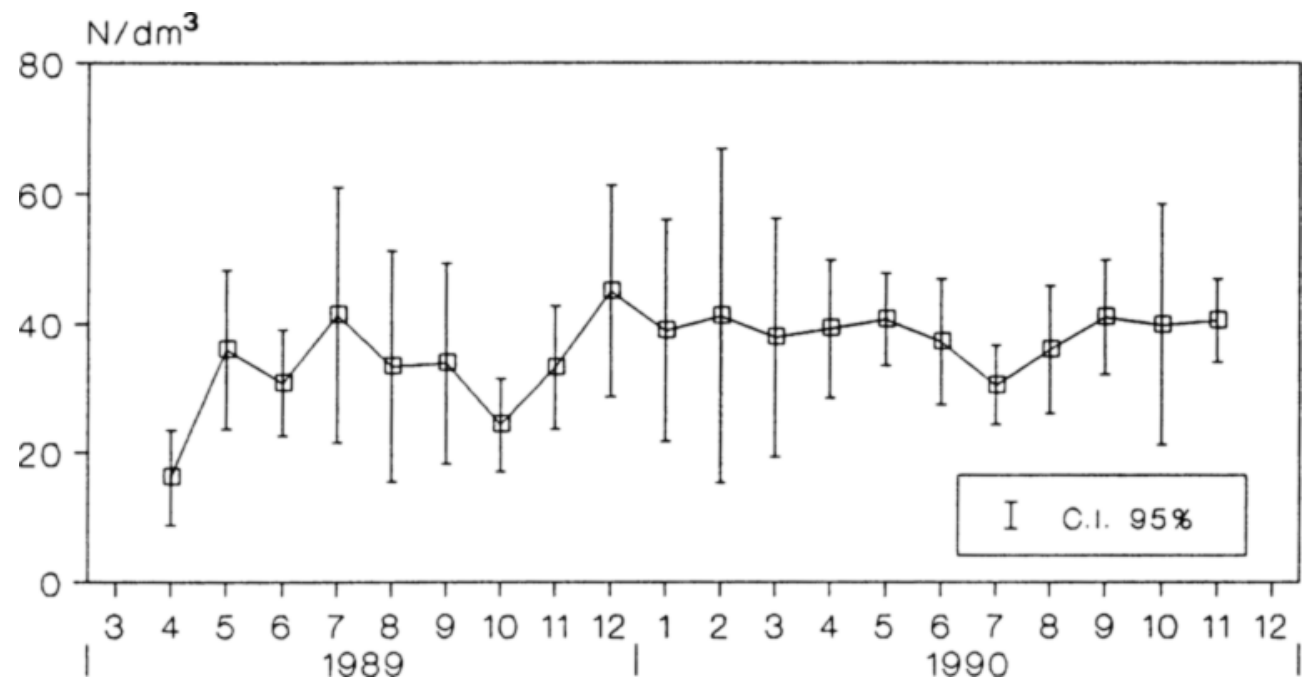

Fig. 2. Monthly changes in the density $\left(\mathrm{N} / \mathrm{dm}^{3}\right)$ of the Lithophaga lithophaga population in the $\mathrm{N}$. Evoikos Gulf. C. I. $95 \%$ : confidence intervals for $95 \%$ probability

Minimum population density values were recorded in October 1989 and July 1990, i.e. 24.33 and 30.5 individuals/ $/ \mathrm{dm}^{3}$, respectively. Maximum values were recorded in December 1989 and September 1990, i.e. 45 and 41 individuals $/ \mathrm{dm}^{3}$ net substratum volume, again respectively.

The average population density decreased with increasing depth down to 3-4 $\mathrm{m}$, and increased slightly down to $6 \mathrm{~m}$ (Fig. 3), in relation to the increasing gradient of the substratum. These changes were not statistically significant $(F=2.13, P=0.175)$. The highest recorded values were at depths of $0-1 \mathrm{~m}$ with an average density of 42.25 individuals/ $\mathrm{dm}^{3}$ and a substratum gradient of $140^{\circ}$. At depths of between $1-6 \mathrm{~m}$ the average densities were 32.55-36.85 individuals $/ \mathrm{dm}^{3}$ with substrate gradients of 50-90.

The sampled surface areas were compared initially by month and depth. Two-way ANOVA showed that there were no statistically significant differences between depths $(\mathrm{F}=0.62, \mathrm{P}=0.69)$ and months $(\mathrm{F}=2.39, \mathrm{P}=0.11)$.

The average surface area of the samples $\left(382 \mathrm{~cm}^{2}\right)$ did not differ statistically from a surface area of $20 \times 20 \mathrm{~cm}$ ( $\mathrm{t}$-test: $\mathrm{N}=24, \mathrm{t}=-0.92<\mathrm{t}_{0 / 0.05}=2.069, \mathrm{~N}=24, \mathrm{P}=0.37$ ). Thus, the average population density of $L$. lithophaga was 36 individuals $/ \mathrm{dm}^{3}$ (equivalent to 36 individuals $/ 0.04 \mathrm{~m}^{2}$ or 56 individuals $/ 0.0625 \mathrm{~m}^{2}$ or 900 individuals $/ \mathrm{m}^{2}$ ) which occupied $23.15 \pm 4.25 \% \mathrm{SD}$ of the net substratum volume.

The highest density, 91 individuals $/ \mathrm{dm}^{3}$ (142 individuals $/ 0.0625 \mathrm{~m}^{2}$ ), was recorded in February 1990 at a depth of $6 \mathrm{~m}$, and occupied only $4 \%$ of the net substratum volume. 
In October 1990, a density of 74 individuals $/ \mathrm{dm}^{3}$ (116 individuals $\left./ 0.0625 \mathrm{~m}^{2}\right)$ at a depth of $0-1 \mathrm{~m}$ was recorded and occupied $38 \%$ of the net substratum volume.

The volume of substratum occupied by $L$. lithophaga was not the same at all depths: ANOVA : $\mathrm{N}=119, \mathrm{~F}=48.98, \mathrm{P}<0.05$ (Fig. 3). This difference was most evident close to the sea-bed. At all other depths, there were no statistically significant differences between the volume of the individuals in relation to the net substratum volume (ANOVA: $N=100, F=0.79, P=0.531$ ).

\section{Spatial distribution}

The index of dispersion (I) showed that Lithophaga lithophaga were aggregated in the study area during the winter months. During the rest of the year the spatial distribution was random (Table 1). The more detailed Morisita index (I $\delta$ ) gave the same results as index $\mathrm{I}$. The equation for the linear regression of the average number of individuals $(\overline{\mathrm{x}})$ on the mean crowding index $(\dot{\mathrm{m}})$ was $: \dot{\mathrm{m}}=-2.92+1.18 \overline{\mathrm{x}}$. Since $\mathrm{b}$ does not differ significantly from $1(\mathrm{P}>0.05)$, L. lithophaga are randomly distributed in the study area.

The dispersion indices (I and $\mathrm{I} \delta$ ) indicated that L. lithophaga occurred in clumps at all depths, except for $3 \mathrm{~m}$ where the distribution was random (Table 2). The linear regression equation of the average number of individuals $\left(\overline{\mathbf{x}}_{\mathrm{d}}\right)$ on the mean crowding index (m) was $\stackrel{*}{m}=-1.9+1.19 \bar{x}_{d}$. Since b does not differ significantly from $1(\mathrm{P}>0.05)$, the individuals were randomly distributed in the study area and between different depths.

\section{Size frequency distribution}

From the length frequency distribution histograms of the total population from June to November 1989 and all of 1990 (Fig. 4), the following can be ascertained. Young individuals with a length of $<4 \mathrm{~mm}$ comprised the largest percentage of the population, i. e. 12.8 and $14.86 \%$ in 1989 and 1990, respectively. The percentage of bigger individuals within the population decreased correspondingly. Individuals of about $15 \mathrm{~mm}$ represented $1 \%$ of the population and those in the range between $15-52 \mathrm{~mm}$, less than $2 \%$. Individuals with a length of $52-80 \mathrm{~mm}$ occurred with a slightly higher percentage $(<4 \%)$ in relation to the next smallest length-class. The percentage gradually decreased to zero for individuals $>80 \mathrm{~mm}$. Significant differences were not obtained in the percentage occurrence of the length-classes between the two years of the study.

\section{Recruitment}

Settled Lithophaga lithophaga spat had a shell length of $>260 \mu \mathrm{m}$. The first juvenile L. lithophaga which settled on pieces of rock placed in the sea were recorded after September 1990 and had lengths of between 393-560 $\mu \mathrm{m}$, with an average length of $420 \mu \mathrm{m}$. The highest density of newly settled individuals $\left(6.9\right.$ individuals $\left./ \mathrm{dm}^{3}\right)$ was recorded in November, two months after the highest occurrence of larvae in the water. In December,

Fig. 3. Schematic representation of the vertical section of the study area where the variation of the mean density $\left(\mathrm{N} / \mathrm{dm}^{3}\right)$ of Lithophaga lithophaga and the percentage relation of the animals' volume to the substrate volume at different depths $\left(\mathrm{V}_{\mathrm{i}} / \mathrm{V} \%\right)$ are shown 


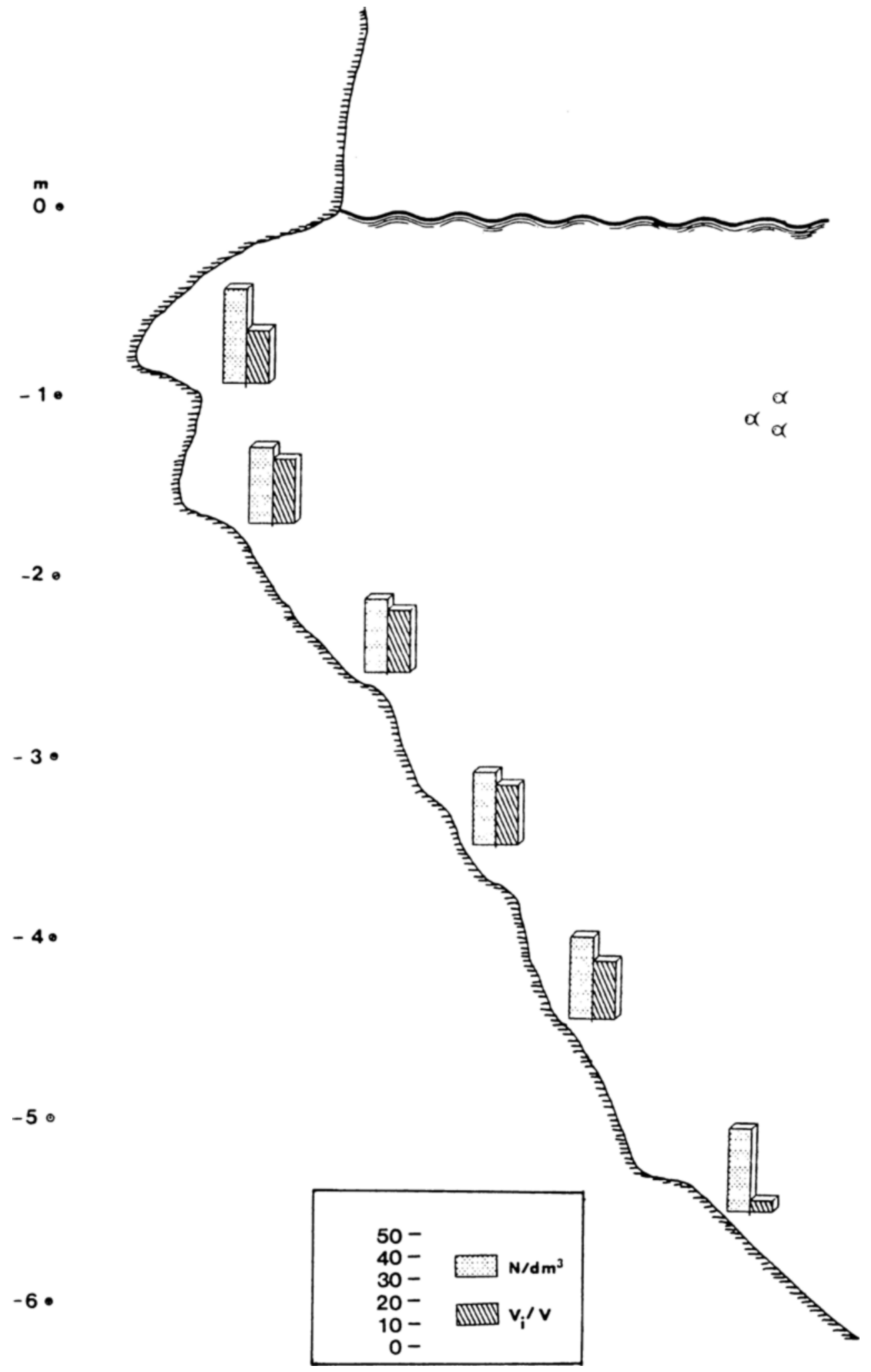


Table 1. Dispersal indices used to determine the spatial distribution of Lithophaga lithophaga during the investigation from April 1989 to November 1990. $\mathrm{s}^{2}$ : variance of the mean number $\overline{\mathrm{x}}$ of date mussels in the sampling units; $n$ : number of sampling units; I and $I \delta$ : dispersal indices; $\chi^{2}{ }_{1}$ and $\chi^{2}{ }_{18}$ : testings of the dispersal indices respectively; m: crowding index

\begin{tabular}{|c|c|c|c|c|c|c|c|c|}
\hline $\begin{array}{l}\text { Sampling } \\
\text { months }\end{array}$ & $\mathrm{n}$ & $\overline{\mathbf{x}}$ & $s^{2}$ & I & I $\delta$ & $x_{1}^{2}$ & $x^{2}$ & $\dot{\mathrm{m}}$ \\
\hline $4 / 1989$ & 5 & 16.20 & 34.69 & 2.14 & 1.26 & $10.70^{\cdots}$ & 24.80 & \multirow{20}{*}{$\begin{array}{l}\dot{\mathrm{m}}=-2.92+1.18 \overline{\mathrm{x}} \\
\mathrm{b}=1.18 \pm 0.25 \\
\mathrm{~b}=1 \text { for } \mathrm{t}_{\mathrm{n}-2} \text { and } \\
\mathrm{P}>0.05\end{array}$} \\
\hline $5 / 1989$ & 6 & 36.00 & 138.06 & 3.72 & 1.07 & 18.60 & 20.05 & \\
\hline $6 / 1989$ & 6 & 30.83 & 60.53 & 1.96 & 1.03 & $9.80^{\circ}$ & 10.52 & \\
\hline $7 / 1989$ & 6 & 41.33 & 351.19 & 8.50 & 1.15 & 42.50 & 42.05 & \\
\hline 8/1989 & 6 & 33.33 & 286.62 & 8.60 & 1.19 & 43.00 & 42.81 & \\
\hline 9/1989 & 6 & 33.83 & 216.97 & 6.41 & 1.13 & 32.05 & 31.26 & \\
\hline $10 / 1989$ & 6 & 24.33 & 47.06 & 1.93 & 1.03 & $09.65^{\circ}$ & $9.35^{\circ}$ & \\
\hline $11 / 1989$ & 6 & 33.17 & 82.08 & 2.47 & 1.04 & $12.35^{\circ}$ & $12.92^{\circ}$ & \\
\hline $12 / 1989$ & 6 & 45.00 & 243.05 & 5.40 & 1.08 & 27.00 & 26.52 & \\
\hline $1 / 1990$ & 6 & 38.83 & 165.69 & 6.84 & 1.13 & 34.20 & 35.16 & \\
\hline $2 / 1990$ & 6 & 41.17 & 598.78 & 14.54 & 1.28 & 72.70 & 73.88 & \\
\hline $3 / 1990$ & 6 & 37.83 & 307.65 & 8.13 & 1.16 & 40.65 & 41.16 & \\
\hline $4 / 1990$ & 6 & 39.17 & 102.62 & 2.62 & 1.03 & $13.10^{\cdots}$ & $12.02 \cdots$ & \\
\hline $5 / 1990$ & 6 & 40.67 & 45.02 & 1.11 & 1.00 & $5.55^{\circ}$ & $5.00^{\circ}$ & \\
\hline $6 / 1990$ & 6 & 37.17 & 86.12 & 2.32 & 1.03 & $11.60^{\circ}$ & $11.66^{\circ}$ & \\
\hline 7/1990 & 6 & 30.50 & 34.34 & 1.13 & 1.00 & $5.65^{\circ}$ & $5.00^{\circ}$ & \\
\hline $8 / 1990$ & 6 & 36.00 & 87.98 & 2.44 & 1.03 & $12.20^{\circ}$ & $10.55^{\cdots}$ & \\
\hline $9 / 1990$ & 6 & 41.00 & 71.57 & 1.75 & 1.02 & $8.75^{\circ}$ & $9.90^{\circ}$ & \\
\hline $10 / 1990$ & 6 & 39.83 & 314.71 & 7.90 & 1.15 & 39.50 & 40.70 & \\
\hline $11 / 1990$ & 6 & 40.50 & 37.09 & 0.92 & 1.00 & $4.60^{\circ}$ & $5.00^{\circ}$ & \\
\hline
\end{tabular}

Table 2. Mean density $\bar{x}$ (number of individuals $/ \mathrm{dm}^{3}$ ) of Lithophaga lithophaga individuals, the percentage of respective volume $R_{v}(\%)$ they occupy in the net substrate at different depths (d) or totally $(\mathrm{t})$ and the dispersal $\left(\mathrm{I}_{\mathrm{d}}, \mathrm{I}_{\mathrm{\delta}(\mathrm{d})}\right)$ and crowding $(\dot{\mathrm{m}})$ indices. $\mathrm{n}_{\mathrm{d}}$ : number of sampling units; $\mathbf{s}_{\mathrm{d}}{ }^{2}$ : variance of $\bar{x}_{d \mid} ; X^{2}{ }_{1 \delta}, \chi^{2}{ }_{I \delta(d)}$ : testings of the spatial distribution indices; $\dot{m}$ : crowding index

\begin{tabular}{|c|c|c|c|c|c|c|c|c|}
\hline $\begin{array}{l}\text { Depth } \\
\text { (d) }\end{array}$ & $\overline{\mathrm{x}}_{\mathrm{id}}$ & $\begin{array}{l}\mathrm{R}_{\mathrm{v}} \\
(\%)\end{array}$ & $\mathrm{n}_{\mathrm{d}}$ & $s_{d}^{2}$ & $I_{d}$ & $I \delta_{|d|}$ & $X^{2}{ }_{\text {dd }}$ & $x^{2}: \delta(d\}$ \\
\hline 1 & 42.25 & 24 & 20 & 182.4 & 4.32 & 1.07 & 82.00 & 78.00 \\
\hline 2 & 34.15 & 29 & 20 & 109.3 & 3.20 & 1.06 & 60.81 & 59.92 \\
\hline 3 & 32.55 & 27 & 20 & 60.0 & $1.84^{\circ}$ & $1.02^{\circ}$ & 35.02 & 32.00 \\
\hline 4 & 32.85 & 28 & 20 & 161.0 & 4.90 & 1.11 & 93.12 & 91.16 \\
\hline 5 & 36.85 & 26 & 20 & 150.8 & 4.09 & 1.08 & 77.34 & 77.88 \\
\hline 6 & 37.42 & 5 & 19 & 431.1 & 11.52 & 1.27 & 207.32 & 209.70 \\
\hline $\begin{array}{l}\bar{x} t \\
\bar{R}_{v(t)} \%\end{array}$ & $\begin{array}{r}35.83 \\
6.67\end{array}$ & $\begin{array}{r}23.15 \\
4.50\end{array}$ & \multicolumn{2}{|c|}{$\dot{\mathrm{m}}=-1.9+1.19 \overline{\mathrm{x}}_{\mathrm{d}}$} & \multicolumn{3}{|c|}{$\begin{array}{l}b=1.19 \pm 0.98 \\
b=1 \text { for } t_{n-1} \text { and } P>0.05\end{array}$} & \\
\hline
\end{tabular}




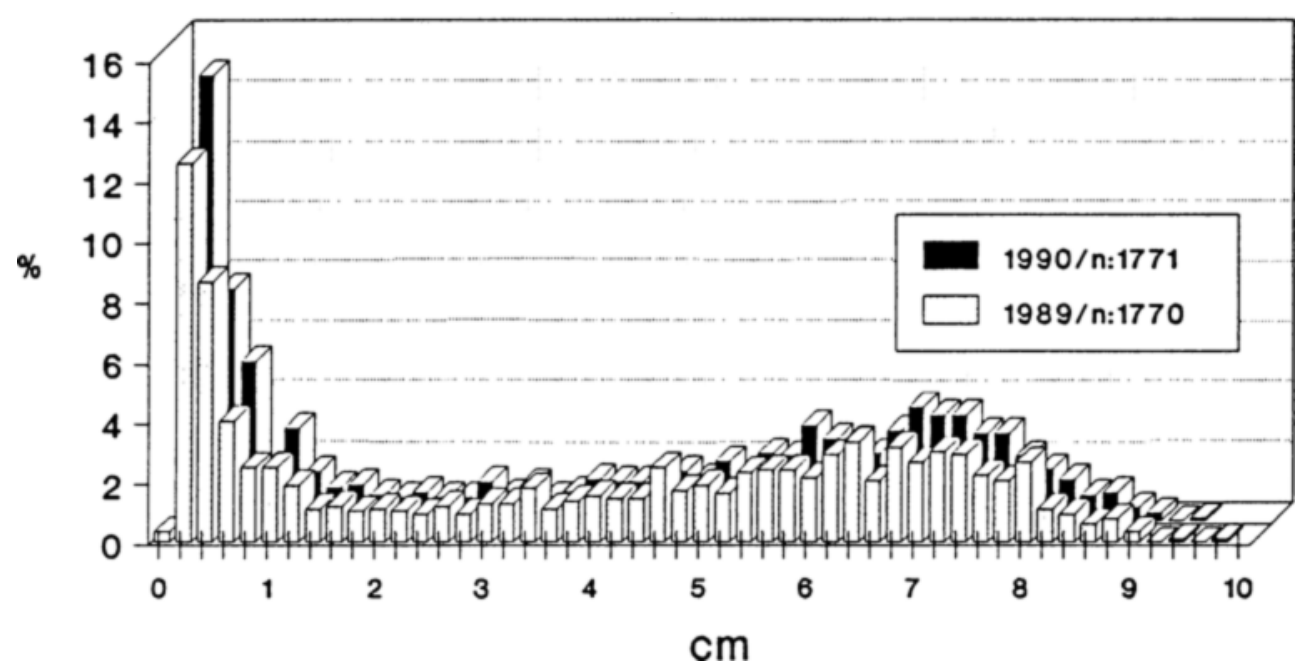

Fig. 4. Frequency distribution of the lengths of the Lithophaga lithophaga population during the period from June 1989 to November 1990. Range of class: $0.2 \mathrm{~cm}$; : number of individuals

the settlement density decreased to 2 individuals $/ \mathrm{dm}^{3}$ and the average length increased to $570 \mu \mathrm{m}$.

Monthly changes in larval length, which was evaluated using individuals cultured in the laboratory (Galinou-Mitsoudi, 1994) and 33 individuals recently settled on the pieces of rocks, are given in Figure 5. It was observed that after metamorphosis and settlement, shell length increased rapidly up to an age of 6 months. Thereafter, growth rate decreased but then increased again after the individuals were 8 months old (length of $1.5 \mathrm{~mm}$ ).

Spat density varied over the course of the year. Lowest densities were recorded in October 1989 and September 1990, while highest densities were recorded in winter and spring months.

The percentage numbers of spat varied over the time. Settlement was recorded in both years of the study (1989 and 1990) during the first winter months, at depths of between 3-6 $\mathrm{m}$, followed by depths of between 0-3 $\mathrm{m}$. A total number of 747 spat were used in calculations, representing $23 \%$ of the total number of individuals collected from June 1989 to November 1990 (Fig. 6).

From the monthly length frequencies (Fig. 7), the following were ascertained : (a) the smallest individuals collected belong to length-classes $0.5-1.0 \mathrm{~mm}$ and $1.0-1.5 \mathrm{~mm}$. They were collected in October-November 1989 and September 1990 respectively, after the commencement of the reproductive period. Water temperatures were $<25^{\circ} \mathrm{C}$, salinity $>32 \%$ and dissolved oxygen was $>8 \mathrm{mg} \cdot \mathrm{l}^{-1}$ during both years; (b) individuals of the $0.5-1.0 \mathrm{~mm}$ length class collected in October 1989 belonged either to the $25-30$ or 30-35 mm length-classes in the following October. The biggest increase in length was recorded from April to September 1990; (c) after the first year, juveniles reached a mean length of $35 \mathrm{~mm}$. 


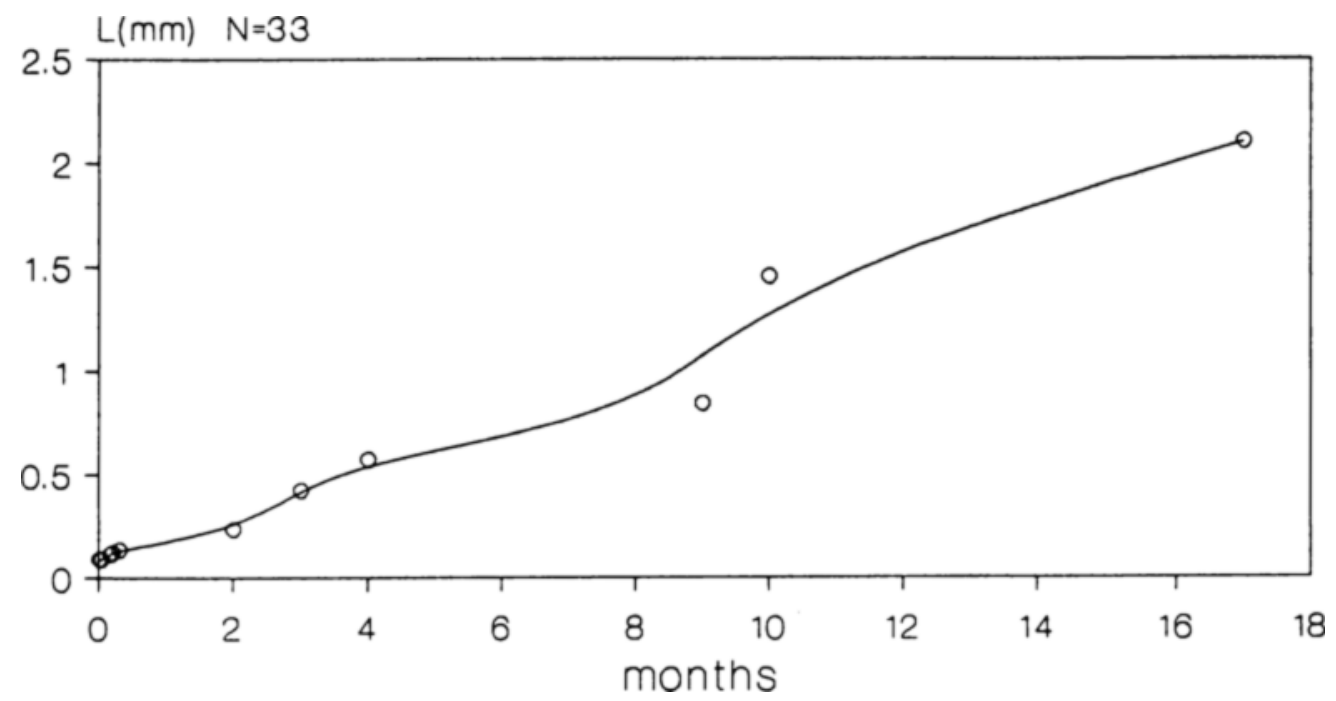

Fig. 5. Monthly growth (L) of Lithophaga ithophaga larvae and spat during the first months of their life

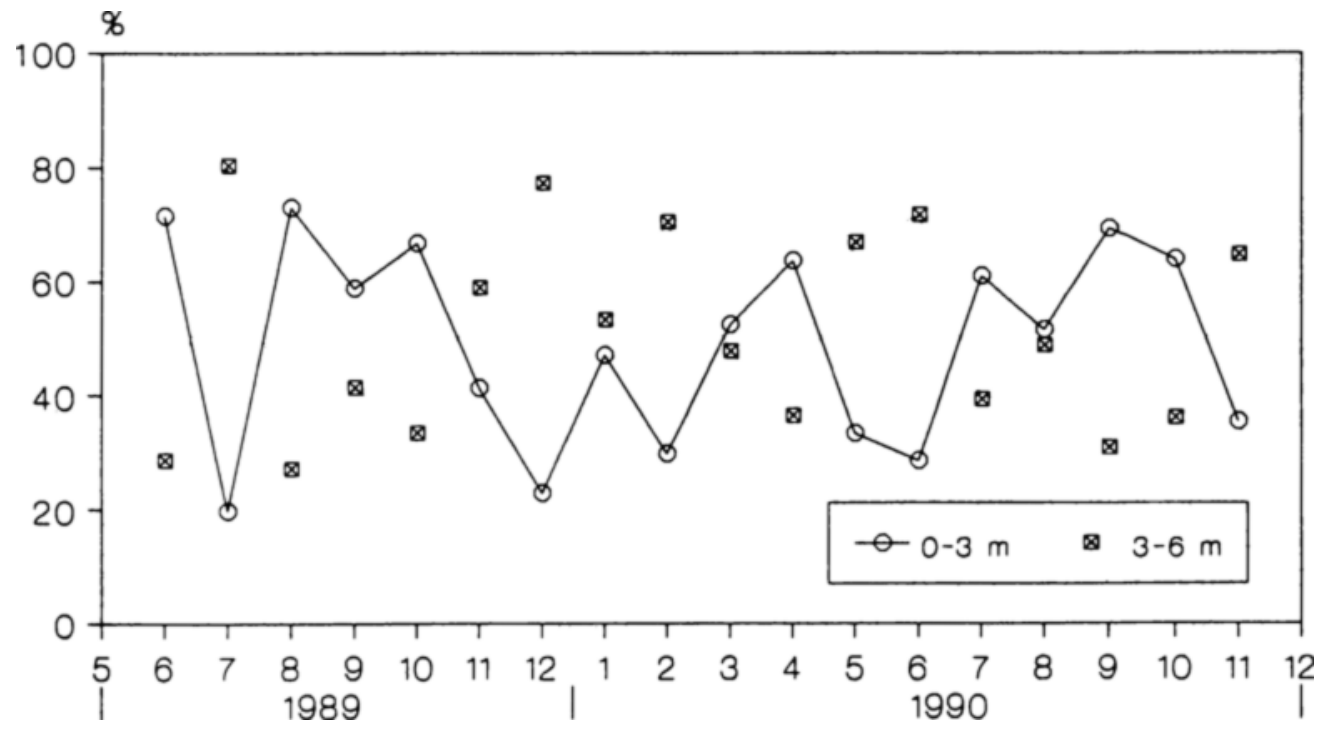

Fig. 6. Monthly changes in the percentage (\%) of Lithophaga lithophaga spat in relation to depth

The average length of all the Lithophaga lithophaga $(\leq 0.4 \mathrm{~cm})$ varied with time (Fig. 8a). The yearly minima (November 1989 and July 1990) were followed almost immediately by yearly maxima (December 1989 and September 1990). It was noted that after the months where maximum values were recorded, the average length of the individuals decreased gradually and then stabilised for 3 months (August-October 1989 and February-April 1990). 

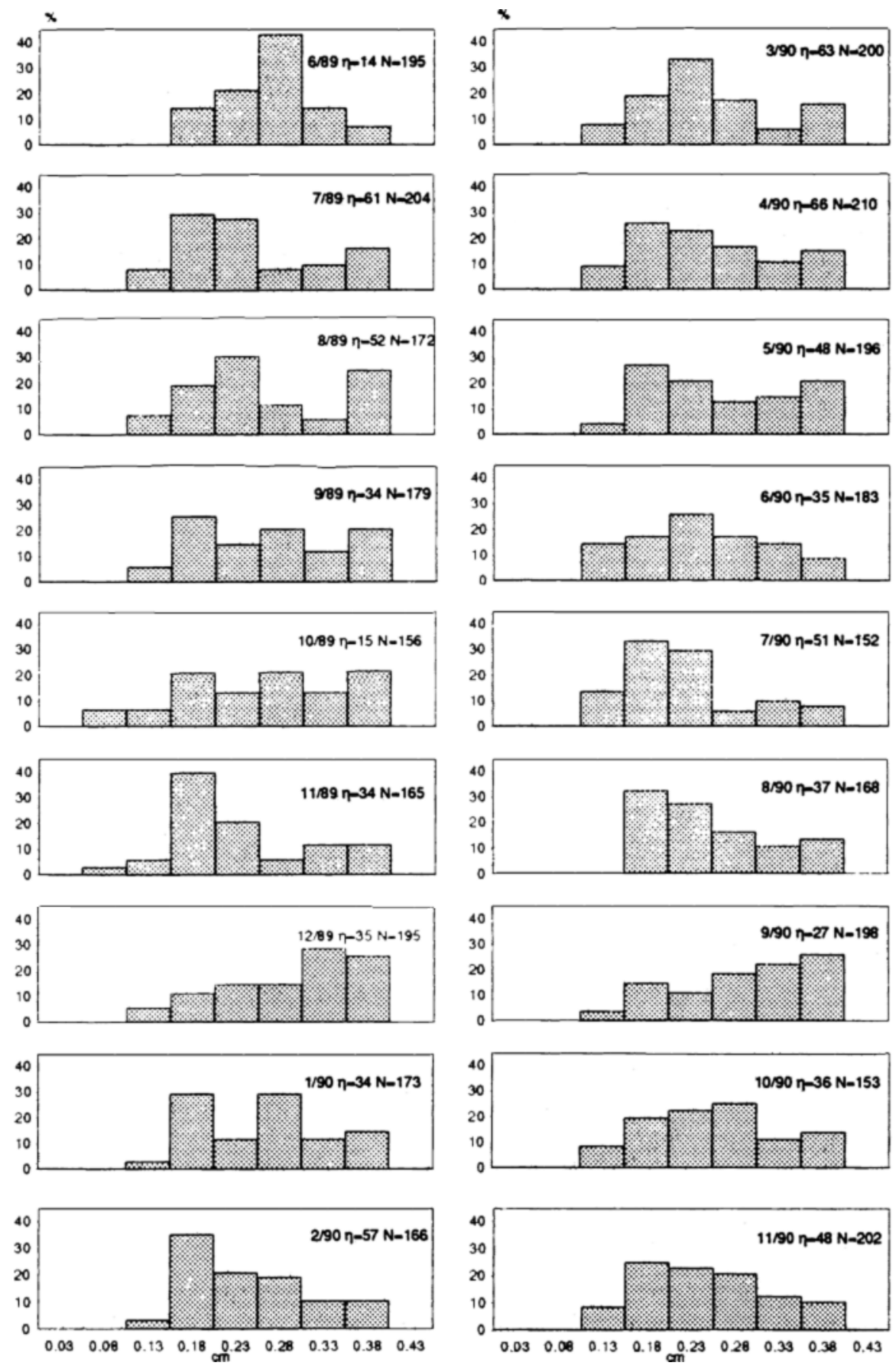

Fig. 7. Length frequency distributions (length class $0.05 \mathrm{~cm}$ ) for Lithophaga lithophaga spat individuals during the period from June 1989 to November 1990. $n$ : number of spat; $N$ : total number of individuals 
There was little change in the average length of the spat during the course of the study for the two depth groups (0-3 and 3-6 m), apart from October 1989 and September 1990. In these months, the average length of the juveniles at a depth of $0-3 \mathrm{~m}$ was larger than that of those at $3-6 \mathrm{~m}$ (Fig. $8 \mathrm{~b}$ ).

From the analysis of the length frequency distribution histograms (method of Hazen according to Harding, 1949) it was ascertained that only one age-group had lengths $\leq 35 \mathrm{~mm}$ and that monthly changes in it (Fig. 9) were not large. In September 1989 and July 1990 a decrease in the average length of the individuals was recorded. There was no change in the average length of spat from February up to and including June 1990.
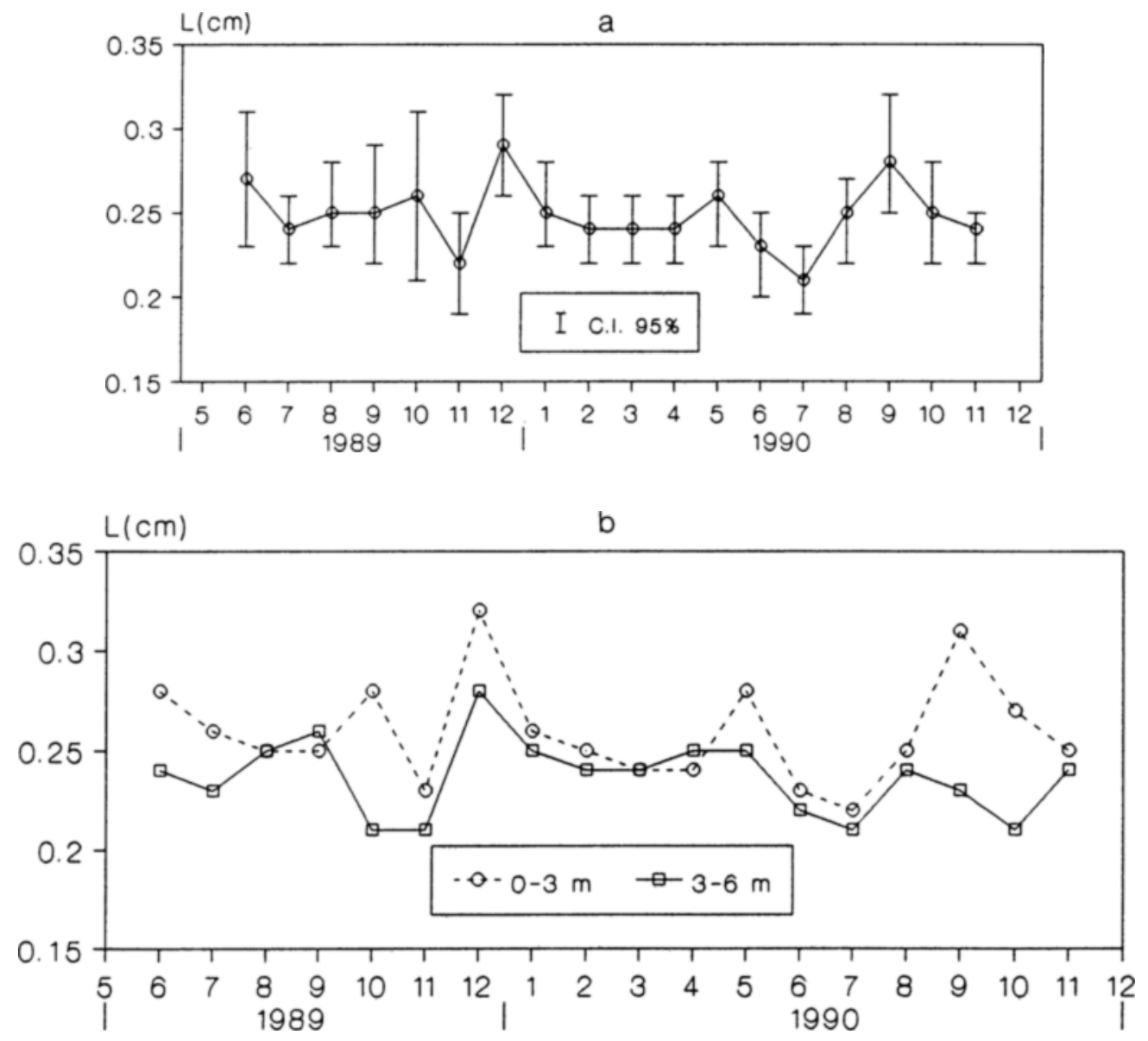

Fig. $8 \mathrm{a}+\mathrm{b}$. Monthly changes in the mean length (L) of Lithophaga lithophaga spat; a: irrespective of depth; b: in relation to depth. C.I. $95 \%$ : confidence intervals for $95 \%$ probability 


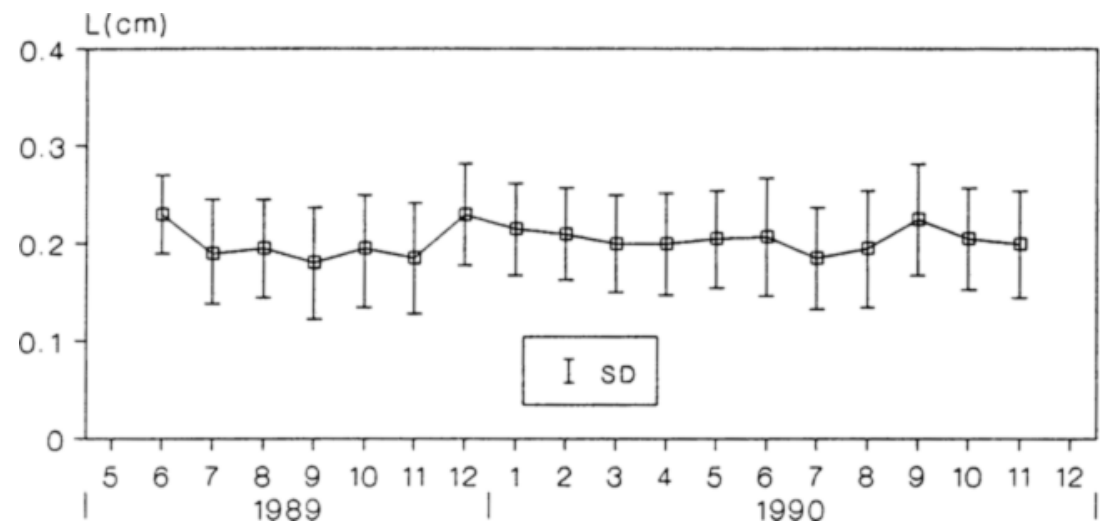

Fig. 9. Density analysis of Lithophaga lithophaga spat using Hazen's graphical probability method for the period from June 1989 to November 1990. SD: standard deviation

\section{DISCUSSION}

\section{Population}

The study area is exposed to prevailing $\mathrm{N}$ and $\mathrm{NE}$ winds with an intensity of up to 9 on the Beaufort scale. The Evoikos Gulf is also characterised by a strong tide (Leontaris, 1984-85).

The substratum of the study area in the N. Evoikos Gulf is limestone, the gradient of which varies with depth. The average population densities of Lithophaga lithophaga also show changes with depth and with gradient, in agreement with Kleemann (1973).

Quantitative measurements of $L$. lithophaga population density have only been reported by Kleemann (1973) for the N. Adriatic Sea. Taramelli et al. (1977) showed that small individuals of $5 \mathrm{~mm}$ average length settled at densities of between 1-3 individuals/ $20 \times 20 \mathrm{~cm}$, surface area, and their presence decreased gradually to zero from $0-6 \mathrm{~m}$ depth.

The maximum (116 and 142 individuals $/ 0.0625 \mathrm{~m}^{2}$ at $0-1$ and $6 \mathrm{~m}$, respectively) and the average maximum population densities (56 individuals $/ 0.0625 \mathrm{~m}^{2}$ ) in the $\mathrm{N}$. Evoikos Gulf, compared with those (100 and 48 individuals $/ 0.0625 \mathrm{~m}^{2}$ ) of the N. Adriatic Sea, differ in terms of values and the depth at which they were recorded. Possible reasons for these differences are considered to be: (a) the difference in gradient; (b) the degree of substratum hardness; (c) the hydrodynamics (tide, waves) of the region; (d) the collection of a relatively large number of young $L$. lithophaga in the N. Evoikos Gulf with a length of between 1-3 mm using a sieve of $0.5 \mathrm{~mm}^{\mathrm{mesh}}$ (e) the intensity of date mussel exploitation (Fischer et al., 1987) and (f) the sampling season.

The maximum numbers of young individuals recorded from the N. Evoikos Gulf was at $6 \mathrm{~m}$ depth on stones. It is possible that these stones originated from either (1) relatively recent landslides from the upper littoral zone and that the individuals which colonised them are young and of small size, or (2) originate from the breaking of rocks during date mussel harvesting $(>5 \mathrm{~cm}$ ) for commercial use. The detached pieces of rock fall to the 
seabed and contain only small individuals. When these pieces of rock are large enough not to be moved by currents or by other factors, the contained date mussels:

(a) die when the borehole opening is facing the surface of the sea (Kleemann, 1973) or facing the sea bottom. Shells of dead L. lithophaga in such stones were full of mud and other material, i.e. detritus.

(b) survive in the other positions.

The densities reported for the N. Adriatic Sea by Kleemann (1973) and those for the N. Evoikos Gulf, in this study, are much higher than densities reported for other species of the same genus, such as, L. plumula $\left(9\right.$ individuals $/ \mathrm{dm}^{3}$ ) in California, USA (Haderlie, 1980a) and L. bisulcata (0.21 individuals/kg substrate) in Jamaica (Scott, 1988).

\section{Spatial distribution}

The spatial distribution of Lithophaga lithophaga is random from the last months of spring to the first months of winter. During winter and spring, an increased density was recorded which is attributed to an increase in group size.

The occurrence of this kind of distribution is identical to the time of recruitment. A similar distribution was observed by Kosler (1968) for the bivalve Mya arenaria, although L. lithophaga has a non-random - variable distribution in corals (Scott, 1988).

Views appear to differ with regard to the general type of distribution of animals in a substratum. Clark \& Milne (1955) and Hughes (1970) report that, in the sub-littoral zone, the distribution of animals is random, as is also recorded here for the distribution of the L. lithophaga population in the N. Evoikos Gulf. Kosler (1968) found that in the eulittoral zone, distributions were typically contagious. Depending on the appropriate availability of substratum and predation (Gaucher, 1965, cited in Hughes, 1970), this leads to the random distribution of clumps.

Downing \& Downing (1992) carried out a study of the spatial aggregation of 76 populations of the freshwater mussel species and found aggregation in $53 \%$ of the cases. Downing \& Downing (1992) believed that these differences were due to the size and number of sampling units and also to population density. They suggested 5 sampling units as being suitable for an average population density of 100 individuals $/ \mathrm{m}^{2}$. It should be noted that in this study, 6 sampling units were used for an average population density of 900 individuals $/ \mathrm{m}^{2}$.

\section{Length frequency distribution}

The presence of spat (Fig. 4) implies that up to a length of $\leq 0.4 \mathrm{~cm}$ and an age of about 1 year, the young Lithophaga lithophaga manage to survive with larger conspecifics. This advantageous condition appears to be lost relatively quickly (in a period of about 5 years) and could be due to intraspecific and interspecific competition, as follows:

- in competition for free space for the boreholes between conspecifics either already settled or in the process of settling

- in cases where the borehole crosses the borehole of either larger individuals or of other endolithic species, mainly bivalves

- the covering of the borehole by other organisms, such as sponges, i.e. Cliona

- increased mortality of spat (Lutz \& Kennish, 1992)

- to physicochemical parameters and to predation (Lutz \& Kennish, 1992). 
Kleemann (1974) reports cases of L. lithophaga borehole crossing and survival depending upon: (a) the size of the animal; (b) the rate of opening of the borehole; (c) the condition of the periostracum and (d) on the general physical condition of the mussel.

Hancock (1973, cited in Brousseau \& Baglivo, 1988) suggests that competition for food and space between spat and adults can cause a reduction in juvenile survival. In addition, Hancock (1973, cited in Caddy, 1989) proposed that the highest competition rates can be expected from individuals which settled in the previous year.

L. lithophaga at lengths of between $15-52 \mathrm{~mm}$ are between 6-25 or even up to 36 years of age. They comprise $20-25 \%$ of the population and are affected mainly by

- the suitability of the substratum for the normal growth of their shells (Kleemann, 1973)

- other larger-sized endolithic organisms, mainly bivalves, either of the same or different species, when these cross their path during the excavation of their boreholes

- predation (Haderlie, 1980b).

Individuals of lengths between $5.2-8.0 \mathrm{~cm}$ and an age greater than between $25-30$ years old are least affected by the above mentioned factors and show a dominance which could be due to their size, physical endurance and successful settlement at the post-larval stage. The reduction in percentage occurrence of individuals $>8 \mathrm{~cm}$ in length is attributed mainly to natural mortality. L. lithophaga of a length $>5 \mathrm{~cm}$ and which comprise about $45 \%$ of the population are commercially exploited.

\section{Recruitment}

Variations in population density of L. lithophaga during the course of the study were due to recruitment in November 1989 and October 1990. Before a new recruitment, the minimum recruitment value for juveniles of the previous years was obtained. These individuals are those which have survived competitors and predators (the main causes of spat mortality; cf. Muus, 1973), dispersion, climatic and food difficulties and an inability to find an appropriate substratum.

From the analyses of spat length (length-classes, temporal changes in relation to depth), there is one age-class, the first $(0+)$, with lengths of up to $3.5 \mathrm{~mm}$. The average length of this class was $1.75-2.50 \mathrm{~mm}$ depending on the method of analysis.

Agius $(1974,1976)$ found one $L$. lithophaga $2.3 \mathrm{~mm}$ long which was active and could move using either its foot or by "swimming" to the water surface and by floating using the opened valves of its shell. Two possible explanations were proposed by Agius (1974, 1976) for the above observation: (a) that it swam out of its borehole or (b) that it had just metamorphosed and was searching for a suitable place to open a borehole. In this study, individuals of $L$. lithophaga of a similar size had metamorphosed, and settled spat of $<2.0$ $\mathrm{mm}$ in length were observed in small cavities and cracks in rocks, in the openings of serpulid tubes on the posterior edges of shells of larger conspecifics and on the anterior and dorsal regions. In many cases it was found that they had already excavated their boreholes. The fact that small, free, L. lithophaga were found in the water by Agius (1974, 1976) could result from byssal detachment.

The appearance of spat in 1989, one month after the start of the reproductive period and, in 1990, two months after, are attributed to inter-annual differences in hydrography (Galinou-Mitsoudi \& Sinis, 1994) which significantly affect the growth of larvae (Loosa- 
noff \& Davis, 1963; Raimbault, 1966; Hrs-Brenko, 1974; Culliney et al., 1975; Meadows \& Campbell, 1972; His et al., 1989). Culliney et al. (1975) and His et al. (1989) consider that temperature is the most important factor affecting larval growth. Temperature remained high in August 1990, while salinity and dissolved oxygen values decreased. These conditions were reversed in September to approach those of October 1989. This possibly caused the spat to appear one month later in 1990 (Fig. 8). The temporal delay in settlement at depths of between $0-3 \mathrm{~m}$ can be attributed to the fact that settlement occurred earlier in the deeper water, where conditions are more stable, i.e. waves, temperature, gradient, so that a reduced value for the average length of the spat was recorded. The opposite occurred at depths of between 0-3 $\mathrm{m}$ where hydrodynamics play a significant role in the time of settlement and growth rate (Tait, 1981; Seed \& Suchanek, 1992). A delay can also be caused by a shortage of food (Lucas, 1982).

Spat density was greater at depths of between 3-6 $\mathrm{m}$ than at depths of between 0-3 $\mathrm{m}$. The average lengths of individuals were greater at depths of between $0-3 \mathrm{~m}$ than between 3-6 $\mathrm{m}$ (Fig. 8b). The negative gradient of the substrate at $0-3 \mathrm{~m}$ depth, exposure to the wave action from the north and northeast, and the local tides are probably reasons which contribute to unstable-unfavourable conditions for settlement, and initial growth. Kautsky (1982) has reported similar findings for Mytilus edulis at depths of between 0-2 $\mathrm{m}$ and also reports that Cardium sp. has a greater settlement at depths of between 3-6 $\mathrm{m}$ than at $0-3 \mathrm{~m}$. The growth of Pecten maximus spat is greater in shallow water where maximum phytoplankton concentrations occur (Thouzeau, 1991). Immediately after the appearance of recruits in the population of L. lithophaga, an increase in the average length of individuals was recorded. This increase is not, however, due to the fast growth of the recruits, but to the slow growth of individuals of the previous year which were already present in the same region.

\section{LITERATURE CITED}

Agius, I., 1974. A comparative survey of the mantles in Lithophaga lithophaga, Mytilus galloprovincialis and Petricola lithophaga with special reference to the boring habit. M. Sc. Thesis, Royal University of Malta, $125 \mathrm{pp}$.

Agius, I., 1976. The rock-boring date mussel Lithophaga lithophaga (L.), (Fam. Mytilidae, Mollusca). - Maltese Nat. 2,65-68.

Brousseau, D. J. \& Baglivo J. A., 1988. Life tables for two field populations of softshell clam, Mya arenaria (Mollusca: Pelecypoda) from Long Island Sound. - Fish. Bull. U.S. 86, 567-579.

Caddy, J. F., 1989. Recent developments in research and management for wild stocks of bivalves and gastropods. In: Marine invertebrate fisheries: their assessment and management. Ed. by J. F. Caddy. Wiley, New York, 665-700.

Clark, R. B. \& Milne, A., 1955. The sublittoral fauna of two sandy bays on the Isle of Cumbrae, Firth of Clyde. - J. mar. biol. Ass. U.K. 34, 161-180.

Culliney, J. L., Boyle, P. J. \& Turner, R. D., 1975. New approaches and techniques for studying bivalve larvae. In: Culture of marine invertebrate animals. Ed. by W. L. Smith \& M. H. Chanley. Plenum Press, New York, 257-271.

Downing, J. A. \& Downing, W. L., 1992. Spatial aggregation, precision, and power in surveys of freshwater mussel populations. - Can. J. Fish. aquat. Sci. 49, 958-991.

Elliott, J. M., 1983. Some methods for the statistical analysis of samples of benthic invertebrates. Freshwater Biol. Ass., Ambleside, 159 pp.

Fischer W., Bauchot, M.-L. \& Schneider, M., 1987. Fiches FAO d'identification des espèces pour les besoins de la pêche. (Révision 1). Méditerranée et mer Noire. Zone de pêche 37 . Volume 1: Végétaux et invertébrés. FAO, Rome, $760 \mathrm{pp}$. 
Galinou-Mitsoudi, S., 1994. Biology and ecology of date mussel Lithophaga lithophaga (Linnaeus, 1758) in Evoikos Gulf. PhD Thesis, Aristotle Univ. Thessaloniki. 270 pp. (In Greek with English abstract).

Galinou-Mitsoudi, S. \& Sinis, A., 1994. Reproductive cycle and fecundity of the date mussel Lithophaga lithophaga (Bivalvia: Mytilidae), - J. moll. Stud. 60, 371-385.

Haderlie, E. C., 1980a. Stone boring marine bivalves from Monterey Bay, California. - Veliger 22, 345-354.

Haderlie, E. C., 1980b. Sea star predation on rock-boring bivalves. - Veliger, 22, 400.

Harding, J. P., 1949. The use of probability paper for the graphical analysis of polymodal frequency distributions. - J. mar. biol. Ass. U.K. 28, 141-153.

His, E. Robert, R. \& Dinet, A., 1989. Combined effects of temperature and salinity on fed and starved larvae of the Mediterranean mussel Mytilus galloprovincialis and the Japanese oyster Crassostrea gigas. - Mar. Biol. 100, 455-463.

Hrs-Brenko, M., 1974. Temperature and salinity requirements for embryonic development of $M y t i$ lus galloprovincialis Lmk. - Thalassia jugosl. 10, 131-138.

Hughes, R. N., 1970. Population dynamics of the bivalve Scrobicularia plana (da Costa) on an intertidal mud-flat in North Wales. - J. Anim. Ecol. 39, 333-356.

Kautsky, N., 1982. Quantitative studies on gonad cycle, fecundity, reproductive output and recruitment in a Baltic Mytilus edulis population. -Mar. Biol. 68, 143-166.

Kleemann, K. H., 1973. Der Gesteinsabbau durch Ätzmuscheln an Kalkküsten. - Oecologia 13 , $377-395$.

Kleemann, K. H., 1974. Raumkonkurrenz bei Ätzmuscheln. - Mar. Biol. 26, 361-364.

Kosler, A., 1968. Distributional patterns of the eulitoral fauna near the isle of Hiddensee (Baltic Sea, Rugia). - Mar. Biol. 1, 266-268.

Leontaris, S., 1984-85. Contribution to the research of the tidal phenomenon of Evripos Strait as related with the coastal configuration of the North and South Evoikos Gulf (in Greek). - Proc. Evoikos Stud. 26, 193-220.

Le Pennec, M., 1980. The larval and post-larval hinge of some families of bivalve molluscs. - J. mar. biol. Ass. U. K. 60, 601-617.

Loosanoff, V. L. \& Davis, H. C., 1963. Rearing of bivalve mollusks, - Adv. mar. Biol. 1, 1-136 pp.

Lucas, A., 1982. La nutrition des larves de bivalves. - Oceanis 8, 363-388.

Lutz, R. A. \& Hidu, H., 1979. Hinge morphogenesis in the shells of larval and early post-larval mussels (Mytilus edulis L. and Modiolus modiolus [L.]). - J. mar. biol. Ass. U.K. 59, 111-121.

Lutz, R., Goodsell, J., Castagna, M., Chapman, S., Newell, C., Hidu, H., Mann, R., Jablonski, D., Kennedy, V., Siddall, S., Goldberg, R., Beattie, H., Falmagne, C., Chestnut, A. \& Partridge, A. 1982. Preliminary observations on the usefulness of hinge structures for identification of bivalve larvae. - J. Shellfish Res. 2, 65-70.

Lutz, R. \& Kennish, M. J., 1992. Ecology and morphology of larval and early postlarval mussels. In: The mussel Mytilus: ecology, physiology, genetics and culture. Ed. by E. Gosling. Elsevier, London, 53-85.

Meadows, P. S. \& Campbell, J. I., 1972. Habitat selection by aquatic invertebrates. - Adv. mar. Biol. $10,271-382$.

Menge, B. A., 1991. Relative importance of recruitment and other causes of variation in rocky intertidal community structure, - J. exp. mar. Biol. Ecol. 46,69-100.

Muus, K., 1973. Settling, growth and mortality of young bivalves in the Oresund. - Ophelia 12 , 79-116.

Raimbault, R., 1966. Reproduction et stades planctoniques des mollusques, - Revue Trav. Inst. Pêch. marit. 30, 257-264.

Scott, P. J. B, 1988. Distribution, habitat and morphology of the Caribbean coral- and rock-boring bivalve, Lithophaga bisulcata (d' Orbigny) (Mytilidae: Lithophaginae). - J. moll. Stud. 54, 83-95.

Seed, R. \& Suchanek, T. H., 1992. Population and community ecology of Mytilus. In: The mussel Mytilus: Ecology, physiology, genetics and culture. Ed. by E. Gosling. Elsevier, London, 87-169.

Tait, R. V., 1981. Elements of marine ecology. Butterworths, London, $356 \mathrm{pp}$.

Taramelli, E., Chimenz, C., Mussino, A., Battaglini, G. \& Bianchi, F., 1977. I Molluschi del porto di Civitavecchia (Roma). - Atti Soc. ital. Sci. nat. 118, 299-314. 
Thouzeau, G., 1991. Experimental collection of postlarvae of Pecten maximus (L.) and other benthic macrofaunal species in the Bay of Saint-Brieuc, France. II. Reproduction patterns and postlarval growth of five mollusc species. - J. exp. mar. Biol. Ecol. 148, 181-200.

Webb, C. M., 1986. Post-larval development of the tellinacean bivalves Abra alba, Tellina fabula, Donax vittatus (Mollusca: Bivalvia), with reference to the late larva. - J. mar. biol. Ass. U.K. 66 . 749-762.

Webb, C. M., 1987. Post-larval development of the bivalves Nucula turgida, Venus striatula, Spisula subtruncata and S. elliptica (Mollusca, Bivalvia), (with reference to the late larva). - J. mar. biol. Ass. U. K. 67, 441-460.

Zar, J. H., 1984. Biostatistical analysis. Prentice-Hall, London, 718 pp. 